\title{
The Risk Management Strategies of Financial Liberalization in China
}

\author{
Shuang-Qing Pan \\ College of Applied Science and Technology, Quanzhou Normal University, Fujian, China \\ E-mail: shuangqingp@ sina.com
}

\begin{abstract}
The impact of financial liberalization on economic growth has two sides. On the one hand, financial liberalization promotes the development of finance, which promotes the economic growth. On the other hand, financial liberalization aggravates the financial fragility, which is more likely to cause the financial crisis, and then destroys the economic growth. This paper analyzes the causes of the risk of financial liberalization, and put forward four strategies of risk management during the financial liberalization in China. They are establishing the concept of efficiency supervision, establishing a multi regulatory system, improving the financial safety net, and promoting the financial liberalization with a proper method.
\end{abstract}

\section{Keywords-Risk Management Strategies; Financial Liberalization; China}

\section{INTRODUCTION}

Since brought forward of the theory of financial liberalization, many countries in the world began financial liberalization reform. However, no matter how perfect the theory of financial liberalization, there is a financial fragility and even the possibility of financial turmoil and financial crisis in the reform practice. Diaz Alejandro (1985) [1] referred clearly that financial liberalization would bring financial risks in his paper "Good-bye Financial Repression, Hello Financial Crash". Therefore, studying the risks of financial liberalization, and the corresponding risk management strategies are necessary.

Financial liberalization is to gradually relax control financial market and financial system, reduce government intervention, increase market function and free competition. The content of financial liberalization is very rich, it includes about four parts: (1) the liberalization of prices. Namely, to cancel the restrictions of interest rate and exchange rate, let market play a role in regulating the price of financial products; (2) the liberalization of business. It allows all kinds of financial institutions across the business, highlighting fair competition; (3) the liberalization of market. It is to reduce the threshold of all kinds of financial institutions to enter the financial market, improve financing tools and technology of the financial market; (4) the liberalization of capital flows. That is to relax the restrictions on foreign capital and foreign financial institutions to enter the domestic market.

\section{A. The Theory of Financial Liberalization}

The theory of financial liberalization was put forwarded for the first time by McKinnon (1973) [2] and Shaw (1973) [3]. In 1970s, financial market incomplete, capital market seriously distorted and government financial intervention and so on was prevalent in developing countries. By the situation of developing countries, they found the harm of financial repression, and put forward the theory of financial liberalization. The core idea of the theory is to relax control on the financial system of government departments, especially the control of interest rate, so as to raise the real interest rate, let it fully reflects the supply and demand of funds. In this way, investors cannot ignore the impact of costs of financing on investment returns, which must be under the conditions of the full measure of the cost of investment and the expected return of investment, so that the efficiency of capital allocation is improved. In addition, high interest rates encourage people to save, so as to provide more funds for investment.

\section{B. The Development of the Theory of Financial Liberalization}

The theory of financial liberalization had also been criticized by some economists. They refuted the theory of financial liberalization by the theory of effective demand, they pointed out once the implementation of financial liberalization, the original inhibited interest rate will rebound, and it is very easy to cause the real interest rate too high and curb investment, thereby inhibiting savings. The reduction of investment will further reduce the economic growth rate through the multiplier effect. The problems exist in the theory of financial liberalization Mackinnon and Shaw were improved by some economists.

For example, economist of Singapore Basnat K. Kapur (1976) [4] and economist of International Monetary Fund Donald J. Mathieson (1980) [5] brought forward Kapur-Mathieson model. The model was based on the financial development model of McKinnon - Shaw, it analyzed the financial, economic growth and economic stability in developing countries, especially how to realize the economic growth and the economic stability through appropriate financial reform in developing countries.

Economist of Spanish Wei Johnson, Vecente Galbis (1977) [6] in the acceptance of McKinnon's basic conclusions and policy proposals, used a two-sector model to amend and supplement McKinnon's one-sector model, the static analysis of Mackinnon and Shaw had been developed into a dynamic analysis. They demonstrated the necessity of financial liberalization from different angles, enriched and developed the idea of financial liberalization, and made the theory of financial liberalization more practical.

Economist of University of California Maxwell J. Fry (1982) [7] proposed a model of opening economic and financial development. Frye corrected and developed 
McKinnon - Shaw's model of financial development, studied the relationship of financial and economic development in developing countries. The core problems of Fry's model are still financial repression and financial deepening in developing countries, and also believe that the outstanding character of financial repression is real interest rates below its equilibrium level. Frye not only further elucidate this problem theoretically, but also through empirical research the actual situation in many developing countries to verify the theory, which makes his model more reasonable, and has more practical application value.

\section{II.THE CAUSES OF THE RISK OF FINANCIAL LIBERALIZATION}

\section{A. Risk of Interest Rate and Exchange Rate Fluctuation}

Liberalization of interest rate is one of the main content of financial liberalization, it allocates funds according to market price, improves the efficiency of the use of funds, and enhances the competitiveness of financial services. After the implementation of the interest rate of market, with the rise in deposit rates, lending rate also tend to raise, the overall rate of interest rate rise, and volatility increase.

Interest rate is volatile, it become more uncertain couple with the uncertainty of market participants' expectations. In addition, the most developing countries implemented a floating exchange rate after the liberalization of interest rate. The fluctuation of the exchange rate was more intense, and affected the interest rate in turn, and thus more drama of the instability of the financial markets. The financial market is vulnerable to a shock, and will cause severe crises.

\section{B. The Risk of Capital Account Opening}

The opening of capital account can make the capital flow from countries with low rate of return on capital to countries with high rate of return on capital, which can reduce the cost of capital, promote investment, improve labor productivity, and increase the output of a country's economy. Of course, the benefits of capital account opening are also associated with the risk of capital account opening.

The opening of the capital account brings a lot of foreign capital inflows, which will bring the pressure of monetary expansion and inflation, bring the appreciation of real exchange rate, and expand the current account deficit. Under the floating exchange rate regime, the imbalance of international payments will lead to currency depreciation, which eventually led to adjustment of the relative price of domestic goods and adjustment of trade flow; under the fixed exchange rate regime, the weak competitiveness of domestic products will lead to international imbalance, hit crawling peg exchange rate regime, cause monetary crisis, and increase instability in financial markets.

\section{The Risk of Improper Reform Method}

A too radical reform method, in the form of a big bang, will bring a lot of problems. If we promote reform of finance liberalization rapidly and comprehensively, then the domestic financial market will subversive for without any buffer process, and easy to form a big impact on the economic and social. In addition, the policy and institutional design with defects cannot get gradually correct and make up under the big bang radical change, and leave endless troubles in the development of the financial and economic afterward.

Many countries suffered the risk from the improper reform method. For example, Chile's liberalization reform is a typical representative of the improper reform, it leaves some painful experience. Demetriades \& Fattouch (1999) [8] through the studied of the South Korean financial crisis, it was found that the financial crisis of South Korea in 1997 was mainly due to the immature financial liberalization and a financial system with problems.

\section{The Risk of Moral Hazard}

The government cancels the credit control after the liberalization of interest rate, credit of financial institutions expands accordingly, together with the cancel of the high reserves of the commercial banks, and the savings banks absorb substantial increase, foreign capital inflows largely with financial liberalization. In order to seize the market share after the liberalization of interest rates, the competition of financial institutions is inevitable, and results in the inflation of credit.

Financial liberalization reduces the industry barriers to entry, reduces the franchise value of the banks and the monopoly profits, so as to reduce the loss brought by the bankruptcy, the banks have greater incentive to invest in risky projects. If the project is successful, banks can get high profits, and obtain competitive advantage. If the project is failure, banks assume limited liability, and the government often provides deposit insurance, which can transfer the loss to other people. Moral hazard is the main risk after the financial liberalization.

\section{E. The Risk of Lack of Supervision System}

When we relax government control, but haven't worked out an accurate and effective supervision program enough to rectify market failure and suppress private speculation, the reform lack of appropriate control system not only hinder increase the efficiency of financial institutions, but also easy to induce a variety of financial crisis.

After the financial liberalization, the loan interest rate ceiling is canceled. The bank in order to obtain high returns, the motivation to provide loans to high-risk projects is very strong. And the risk management of these projects cannot be reached, resulting in poor risk control, a sharp increase in non-performing loans.

\section{THE STRATEGIES OF RISK MANAGEMENT}

\section{A. To Establish the Concept of Efficiency Supervision}

China should reference to the development trend of western financial supervision, establish benefit regulation concept. It requires the People's Bank only stipulate clear goals, does not require specific practices. The supervision of bank is operational risk control, and not the control of bank management behavior, commercial banks can make management choices according to their own situation as to 
meet regulatory standards for the People's Bank. This approach is consistent with the development trend of western financial regulatory philosophy in recent years.

\section{B. To Establish a Multi Regulatory System}

China should improve the legal system and financial regulatory system to avoid systemic financial crisis maximize, the effectiveness of the regulatory environment can restrain the tendency to have a systemic banking crisis of financial liberalization. Traditional regulatory system of the central bank specialized supervision of the supervision mechanism of the state. However, due to the limitations of the independence of bank, the complex and diversification of business, and the existence of moral hazard factors etc., so the supervision mechanism of the state cannot ensure the supervision of financial liberalization. Therefore, we must pay attention to the internal supervision mechanism of banks, the use of self regulatory oversight mechanisms. Similarly, the banking industry self-regulation mechanism should also be included in the regulatory system.

\section{To Improve the Financial Safety Net}

In view of the common moral hazard problems in the financial safety net, the People's Bank of China should carefully use the last lender system, and to improve the efficiency of the central bank's financial supervision more through the market mechanism. The People's Bank should cancel the fully guarantee for the financial institutions, reasonable constraint the investment responsibility, clear the bear share in the crisis of agency debt losses, and establish corresponding incentive mechanism of the market. As a result, the people's Bank will remove the collective non rational behavior which lead to financial panic, at the same time, avoid weakening market discipline function and contribute to the moral risk of banks, then the negative impact induced by regulatory reduce as much as possible to a minimum.

\section{To Promote the Financial Liberalization with a Proper Method}

China should work out reasonable timing arrangement of policies and measures for financial liberalization, guide the financial liberalization in an orderly stages according to economic development maturity and internal logic of economic operation. In condition of macroeconomic instability, economic development is not satisfactory, promote financial liberalization with a passive attitude, intent to reverse the unfavorable situation, the financial liberalization due to the lack of timely and effective supervision mechanism will lead to a series of unexpected problems, the adverse consequences caused by financial liberalization of interest rate and exchange rate fluctuations often immeasurable.

\section{CONCLUSIONS}

We must pay attention to the risks associated with financial liberalization, but we can't stop the pace of financial liberalization because of risks. We should analyze the causes of the risks and construct the corresponding countermeasures of risk prevention. We may establish the concept of efficiency supervision, establish a multi regulatory system, improve the financial safety net, and promote the financial liberalization with a proper method.

\section{ACKNOWLEDGEMENT}

This research was financially supported by China Economic Research Centre of Quanzhou Normal University.

\section{REFERENCE}

[1] Diaz-Alejandro C, "Good-bye Financial Repression, Hello Financial Crash", Journal of Development Economics, Vol. 19, pp. 1-24, 1985.

[2] Mckinnon, R., Money and Capital in Economic Development, Washington, DC: Brookings Institution, 1973.

[3] Shaw, E., Financial Deepening in Economic Development, London: Oxford University Press, 1973.

[4] Basant K., "Kapur. Alternative Stabilization Policies for Less-Developed Economies", Journal of Political Economy, Vol. 84, No. 4, pp. 777-795, 1976.

[5] Donald J. Mathieson, "Financial Reform and Stabilization Policy in a Developing Economy", Journal of Development Economics, vol. 7 , no 3, pp. 359-395, Sep. 1980.

[6] Vicente Galbis, "Financial Intermediation and Economic Growth in Less-Developed Countries: A Theoretical Approach", Journal of Development Studies, Vol. 13, No. 2, pp. 58-59, 1977.

[7] M. J. Fry, "Models of Financially Repressed Developing Economies", World Development, vol.10, No.9, pp. 741-742, 1982.

[8] Demetriades \& Fattouh, "South Korea's Financial Liberalization: An Experiment in Faith", International Affairs, vol.75, no.4, pp. 779-792, 1999. 